\title{
Homelessness and malnutrition
}

\author{
Hans Wolff \\ Dr. Hans Wolff is Head of the Prisoner Health Care Unit at the Department of Community Medicine and Primary Care, \\ University Hospital in Geneva.
}

Prague's homeless do not seem to suffer from energy-density malnutrition. In this issue of IJPH, Kubisovà et al. found only a small proportion of homeless with underweight, wasted muscle mass, low subcutaneous fat or low blood proteins such as albumin which can be used as an indicator of long-term starvation. These results are surprising because alcoholism, a common cause of malnutrition, was frequent (16\%) and almost half of the homeless indicated involuntary weight loss. Furthermore, numerous studies have stated a high prevalence of under-nutrition in homeless people [1, 2]. A plausible explanation for this paradox might be found in the well-functioning local charity organizations which, as stated by the authors, "help to keep nutritional status of reachable homeless at a satisfactory level" (REF). Then which is the interest of this "negative result"-study? Well, if the main purpose of research is to improve population health, it is a good approach to focus on marginalized groups, such as homeless who suffer from exclusion of elementary human rights and high rates of morbidity and mortality [1, 3-6]. Kubisovà's study helps to better understand the health status of homeless and this is the first step to find ways to improve their health.

Homeless people live in a world of exclusion and are mostly refractory to classical strategies to improve access to health care. The frequent denial of their hardly bearable reality is what allows them to survive. At least having the ability to say "no" remains a right that a homeless person doesn't have to share; Health care offers are therefore frequently refused. As health professionals, how can we address this problem? How can we supply good health care to the homeless? The solution must occur at several levels and requires a network of care, easily accessible, which can readily respond to the specific needs of the homeless and other marginalized groups.

Kubisovà et al. hypothesize that Prague's social network prevents under-nutrition in its homeless population, but who takes care of obesity, alcoholism, pulmonary diseases or other health problems? Even a well-functioning social network can be improved when collaborating with medical services in an integrated way. Furthermore, relational and communication skills are crucial, with confidence boosting being of major importance. Aspects of social medicine need to be emphasized in the educational programs of social and health care workers, interdisciplinary collaboration promoted and health care actions systematically monitored and evaluated.

Hans Wolff 


\section{References}

1. Langnase K, Muller MJ (2001). Nutrition and health in an adult urban homeless population in Germany. Public Health Nutr 4(3): 805-11.

2. Tarasuk V, Dachner N, Li J (2005). Homeless youth in Toronto are nutritionally vulnerable. J Nutr 135(8): 1926-33.

3. Vollm B, Becker H, Kunstmann W (2004). [Prevalence of physical diseases, health behavior and health care utilization in single homeless men: a cross sectional study]. Soz Praventivmed 49(1): 42-50.
4. Badiaga S, Menard A, Tissot DH, Ravaux I, Chouquet D, Graveriau C et al (2005). Prevalence of skin infections in sheltered homeless. Eur J Dermatol 15(5): 382-6.

5. O'toole TP, Conde-Martel A, Gibbon JL, Hanusa BH, Fine MJ (2003). Health care of homeless veterans. J Gen Intern Med 18(11): 929-33.

6. Nordentoft M, Wandall-Holm $N$ (2003). 10 year follow up study of mortality among users of hostels for homeless people in Copenhagen. BMJ 327(7406): 81 .

\section{Address for correspondence}

Hans Wolff, MD, MPH

Department of Community Medicine and Primary Care

Centre médical universitaire

Av. de Champel 9

1211 Genève 4

Tel.: +41 22 (37) 95969

Fax: +41 22 (37) 95985

e-mail: hans.wolff@hcuge.ch
To access this journal online: http://www.birkhauser.ch/IJPH 